\title{
How Postcolonial is Post-Western IR? Mimicry and Mētis in the international politics of Russia and Central Asia
}

Catherine Owen, John Heathershaw and Igor Savin

\begin{abstract}
Scholars in International Relations have called for the creation of a Post-Western IR that reflects the global and local contexts of the declining power and legitimacy of the West. Recognizing this discourse as indicative of the postcolonial condition, we deploy Homi Bhabha's concept of mimicry and James C. Scott's notion of mettis to assess whether international political dynamics of a hybrid kind are emerging. Based on interviews with Central Asian political, economic and cultural elites, we explore the emergence of a new global politics of a Post-Western type. We find that Russia substantively mimics the West as a post-Western power and that there are some suggestive examples of the role of metis in its foreign policy. Among Central Asian states, the picture is more equivocal. Formal mimicry and mettis of a basic kind are observable, but these nascent forms suggest that the dialectical struggle between colonial clientelism and anti-colonial nationalism remains in its early stages. In this context, a post-Western international politics is emerging with a postcolonial aspect but without the emergence of the substantive mimicry and hybrid spaces characteristic of established postcolonial relations.
\end{abstract}

Catherine Owen is British Academy Postdoctoral Fellow in the Department of Politics at the University of Exeter. Her research concerns Russian and Chinese politics in comparative perspective. C.A.M.Owen@exeter.ac.uk

John Heathershaw is Associate Professor in International Relations at the University of Exeter and Principal Investigator (2012-2016) of the ESRC Research Project 'Rising Powers and Conflict Management in Central Asia'. His research concerns conflict, security and development in Central Asia, particularly Kyrgyzstan and Tajikistan. J.D.Heathershaw@exeter.ac.uk

Igor Savin is Head of the Department of Central Asia at the Central Eurasia Research Centre, Institute of Oriental Studies, Moscow, Russia, and Leading Research Fellow at the Centre of History and Ethnology at Southern Kazakhstan State University, Shymkent, Kazakhstan. His research concerns conflict, identities, and the integration of migrants in Russia and Central Asia. savigsa@inbox.ru

\section{ACKNOWLEDGEMENTS}

This paper was produced thanks to the time afforded under the ESRC research project Rising Powers and Conflict Management in Central Asia' (ES/J013056/1). 
The wide-ranging debate over 'non-Western' or 'post-Western' theories, histories and futures of International Relations (IR) has proliferated in recent years. ${ }^{1}$ Indeed, at first glance, the architecture of the whole field seems to have shifted away from its traditional home in the US and Europe, with the increasing regionalisation of disciplinary institutions and the inauguration of the ISA South Convention. This shift claims a founding empirical reference point in the displacement of power from the purportedly hegemonic United States, and its post-1945 and post-1989 iterations of international order, to a new multi-polar world where 'rising powers', particularly those of Asia, challenge this hegemony and revise its order. This debate has produced much deliberation about the state of the discipline and how global, universal and scientific we actually are; in particular, Acharya \& Buzan's call for the development of 'non-Western IR' ${ }^{2}$ has elicited a number of responses. ${ }^{3}$ However, this call, while doubtlessly wellintentioned, is ontologically and methodologically problematic, not least in its creation of a binary distinction between 'West' and 'non-West', which blinds us to the co-constitution of West and East, and North and South, in the emergence of the global. Nor will the transformation and regionalization of knowledge production in itself make an American field become global. ${ }^{4}$

This article takes steps towards developing one possible way of doing a more global and distinctly postWestern IR that takes into account both the contemporary shifts in power away from the West and the legacies of the West in the ways in which international politics is talked about (discourses) and enacted (practices). It begins with the recognition that post-Western and postcolonial International Relations have much in common: their focus on power relations between dominant and subordinate actors and a recognition of the effects of imperial legacies in contemporary international politics. Consequently, we offer two concepts drawn from postcolonial theory - Bhabha's idea of mimicry ${ }^{5}$ (both formal, that is simple imitation, and substantive, that is the adaptation and subversion of imperial models ${ }^{6}$ ) and James C. Scott's notion of mētis ${ }^{7}$ (cunning, knack, practical knowledge) - as means through which to explore the overlap between post-Western and postcolonial interactions among state and non-state actors in the contemporary international system. Together, mimicry and mētis conceptualise the ways in which Western and imperial practices are challenged, re-articulated or subverted by subordinate actors at official and everyday levels. Rather than testing a theory with comparative case studies of "rising powers', this research is exploratory and oriented towards conceptual development.

Central Asia provides a promising context in which to explore the interplay of post-Western and postcolonial relations, since Western powers are weak and in decline, and one of the 'emerging powers' in the region, Russia, is the former imperial patron. Therefore, we offer a heuristic approach and regionally specific example of how a postcolonially informed post-Western IR works in practice across two levels: the global, in the resurgence of Russian power, and the regional, in Central Asian states' relations with their former imperial master. We highlight Russia's post-Western features, as a former

\footnotetext{
${ }^{1}$ Throughout this essay, when referring to the discipline, we either capitalise the words 'International Relations' or abbreviate them (IR), but leave them uncapitalised when referring to practices of global politics.

${ }^{2}$ Amitav Acharya and Barry Buzan, 'Why is there no non-Western International Relations theory? An Introduction', International Relations of the Asia-Pacific 7 (2007), pp. 287-312.

${ }^{3}$ Ching-Chang Chen, 'The Absence of non-Western IR Theory in Asia Reconsidered', International Relations of the Asia-Pacific 11 (2011), pp. 1-23; Kimberly Hutchings, 'Dialogue between Whom? The Role of the West/non-West Distinction in Promoting Global Dialogue in IR', Millennium: Journal of International Studies 39:3 (2011), pp. 639-347; Andrey Makarychev and Viatcheslav Morozov, 'Is “Non-Western Theory” Possible? The Idea of Multipolarity and the Trap of Epistemological Relativism in Russian IR', International Studies Review 15 (2013), pp. 328-350.

${ }^{4}$ Ole Wæver and Arlene Tickner, "Introduction: Geocultural Epistemologies" in Arlene Tickner and Ole Wæver (eds.) International Relations Scholarship around the World: Worlding beyond the West, (Abingdon: Routledge, 2009), p. 10.

${ }^{5}$ Homi Bhabha, The Location of Culture, (Abingdon: Routledge, 1994).

${ }^{6}$ L.H.M. Ling, 'Chapter 5: Cultural Chauvinism and the Liberal International Order: "West Versus Rest" in Asia's Financial Crisis' in Chowdhry Geeta and Sheila Nair (eds.), Power, Postcolonialism and International Relations: Reading Race, Gender and Class, (Oxford: Routledge, 2004).

${ }^{7}$ James C. Scott, Seeing Like a State: How Certain Schemes to Improve the Human Condition Have Failed, (New Haven: Yale University Press, 1998).
} 
European-centred empire that shifted from formal to substantive mimicry of the West in the post-Soviet period, which also relies on the formal mimicry and metis developed with Central Asia in the cultural and institutional continuities of the Soviet Union. We sketch Central Asia as post-Western space of global politics, in part, because of its post-colonial relations with Russia. However, our analysis shows that the practices of postcolonial international relations do not map neatly onto those of post-Western international relations: mimicry is most substantive when deployed by Russia vis-à-vis the West, while formal mimicry and mētis allow Central Asians to evade post-imperial domination. The use of mimicry and mētis, 'rising powers' and post-Western IR must be seen not merely in terms of current and future trajectories but in their imperial and colonial pasts. Our study highlights the importance of investigating global politics through Area Studies, whose ethnographic orientation may highlight these continuities and provide empirically grounded theoretical tools for exploring the degree and kind of postcolonial, post-Western relations. ${ }^{8}$

The article draws on fieldwork conducted in 2013-14 in Kyrgyzstan, Tajikistan and Russia. The republics of Kyrgyzstan and Tajikistan are the smallest, poorest and most dependent post-Soviet states and are most likely to illustrate the postcolonial dynamics we seek to explore. Thirty-eight semistructured interviews with Kyrgyz and Tajik business persons, officials and cultural elites, as well as Russian elites, were analysed via two approaches to coding. Firstly, we undertook an initial survey with NVivo software to identify the most prevalent 'nodes' of the discourse about Russia in Central Asia. Secondly, we adopted manual coding to specify aspects of mimicry and mêtis as reported by native and Russian elites. Most interviews were conducted in Russian, the language of empire that remains the lingua franca of the region. Examples are supplemented with findings from our wider research on state institutions, conflict management and security affairs in the post-Soviet region.

The paper is structured as follows. The first section considers three approaches to the contemporary power shifts in the international system, and argues for a postcolonially informed post-Western IR. The second section elaborates mimicry and mētis as tools for uncovering postcolonial, post-Western international relations. The third section sets out Russia as a post-Western and post-imperial power, and highlights its use of substantive mimicry and mêtis of the Western-founded global order. The fourth and final section explores discourses and reported practices of formal mimicry and mêtis in the postWestern and post-colonial relations of Russia in Central Asia.

\section{The Place of the West in Contemporary IR}

In the shadow of the emergence of 'rising powers' and the question of the universality of social science, the debate over the position of the West in a global IR has elicited a plethora of responses. These range from those that doubt or place caveats upon the decline of Western powers, norms and institutions ${ }^{9}$ to doom-mongers of the coming 'age of disorder' and proponents of the 'China threat' thesis. ${ }^{10}$ Many of these responses can be tied genealogically to the debate over the 'unipolar moment' between realists and liberals. ${ }^{11}$ Other scholars have sought to argue for 'non-Western IR' as a mode of inquiry with

\footnotetext{
${ }^{8}$ See Joseph MacKay and Jamie Levin, "Hanging Out in International Politics: Two Kinds of Explanatory Political Ethnography for IR", International Studies Review 17 (2015), pp. 163-188; Wanda Vrasti, “The Strange Case of Ethnography and International Relations", Millennium: Journal of International Studies, 37:2 (2008), pp. 279-301.

${ }^{9}$ Barry Buzan, 'China in International Society: Is "Peaceful Rise” Possible?' The Chinese Journal of International Politics, 3 (2010), pp. 5-36; Michael Cox, 'Power Shifts, Economic Change and the Decline of the West?' International Relations 26:4 (2012), pp. 369-388; G. John Ikenberry. 'The Future of the Liberal World Order: Internationalism after America', Foreign Affairs, May/June 2011.

${ }^{10}$ Randall Schweller, 'Emerging Powers in an Age of Disorder', Global Governance 17:3 (2011), pp. 285-297.

${ }^{11}$ A sub-set of this group are empiricists who deploy the rise/fall monikers as a foil for data-driven analyses of power and/or institutions, typically discovering a mixed picture, but nonetheless one that presents the 'rise' of Asia as a 'threat' to the foundations of liberal internationalism. This camp includes much work in IPE, both historical materialist and moderate constructivist. See Martin Jacques, When China Rules the World: The End of the Western World and the Birth of a New Global Order, 2nd Edition, (London: Penguin, 2012); Miles Kahler, 'Rising Powers and Global Governance: Negotiating Change in a Resilient Status Quo', International Affairs 89:3 (2013), pp. 711-729; Christopher Layne, 'This Time it's Real: The End of Unipolarity and the Pax
} 
theoretical terms and empirical objects that are not tainted by Western theories or themes deemed overly narrow or even 'racist'. ${ }^{2}$ This camp includes those trying to pluralize the study of international politics and those asserting its particularization in national schools of comparative IR theory ${ }_{13}^{13}$ some of which have essentialist overtones. ${ }^{14}$ A third group of scholars have advanced a 'post-Western' approach which seeks to develop a global study of IR, rather than a cluster of incommensurable regional approaches. ${ }^{15}$ This approach is supported by a number of works on the history of IR, which demonstrate that concepts of world politics that extend across regions and cultures may be unearthed through comparative historical examination.

Postcolonial theorists have observed that some responses to the rise of non-Western powers, particularly those from the policy world, are rooted in an ethno-centrism in which the rise of the Other can only be understood as a challenge to the Self. ${ }^{16}$ Here, debates about Rising Powers and their challenge to the system begin and end in these self-referential terms. For example, attempts at both 'saving [the concept of] liberal peacebuilding' and condemning it to an over-due demise both suffer from a profound Western bias. ${ }^{17}$ They both fail to capture the actual power dynamics by which certain contexts become more or less violent and fall short of assessing how and why certain non-Western interveners, notably Russia, have become more active. The debate is necessarily framed in terms of a perceived challenge to a putative Western norm, institution or economic practice. However, neither is the thesis (the Liberal Peace) entirely Western, nor the counter-thesis (the Post-Liberal Peace) entirely non-Western. West versus non-West is simply an unhelpful framing of a debate which takes place at a global level, but where former imperial powers have hitherto set an agenda for former colonies.

This empirical problem is mirrored in theoretical debates. Non-Western approaches purport to offer a pluralist alternative whereby multiple national and regional schools of IR produce different conceptions of international order; in the comparative study of these schools we begin to approach, but never reach, a single, global IR. In his earlier work, Acharya argued that International Relations should locate 'alternative theories' of global politics whose ontological roots lie in the Global South. ${ }^{18}$ Methods for the development of such theories include the incorporation of regional political philosophers, politicians

Americana', International Studies Quarterly 56 (2012), pp. 203-213; Hugh White, The China Choice: Why We Should Share Power, (Oxford: Oxford University Press, 2013); Matthew Stephen 'Rising Powers, Global Capitalism and Liberal Governance: A Historical Materialist Account of the BRICS Challenge', European Journal of International Relations 20:4 (2014), pp. 912-938.

${ }^{12}$ Acharya and Buzan, 'Why is there no non-Western International Relations theory?'; Amitav Acharya, 'Dialogue and Discovery: In Search of International Relations Theories Beyond the West', Millennium: Journal of International Studies 39:3 (2011), pp. 619-637; John Hobson, 'Is Critical Theory always for the white West and for Western imperialism? Beyond Westphilian towards a post-racist critical IR', Review of International Studies 33 (2007), pp. 91-116.

${ }^{13}$ The distinction between Pluralists and Particularists is made by Rosa Vasilaki, 'Provincialising IR? Deadlocks and Prospects in Post-Western IR Theory', Millennium: Journal of International Studies 41:3 (2012), pp. 3-22.

${ }^{14}$ Makarychev and Morozov, 'Is "Non-Western” Theory Possible?'; Yaqing Qin, 'Why is there no Chinese International Relations Theory?' International Relations of the Asia-Pacific 7 (2007), pp. 313-340; Andrei Tsygankov and Pavel Tsygankov, 'National Ideology and IR Theory: Three Incarnations of the "Russian Idea", European Journal of International Relations 16:4 (2010), pp. 663-686; Gregorio Shani, 'Towards a PostWestern IR: The Umma, Khalsa Panth, and Critical International Relations Theory', International Studies Review 10 (2008), pp. 722-734 (who confuses matters by denoting non-Western IR as (proper, valid) 'PostWestern IR').

${ }^{15}$ Chen, 'The Absence of non-Western IR Theory in Asia Reconsidered'; Hutchings, 'Dialogue Between Whom?'; L.H.M. Ling, 'Worlds Beyond Westphalia: Daoist Dialectics and the "China Threat"', Review of International Studies 39:3 (2013), pp. 549-568.

${ }^{16}$ Ling, 'Worlds Beyond Westphalia, pp. 554-5.

${ }^{17}$ Roland Paris, 'Saving Liberal Peacebuilding', Review of International Studies, 6:2 (2010), pp 337-365. (See also Meera Sabaratnam, 'Avatars of Eurocentrism in the critique of the liberal peace', Security Dialogue, 44:3 (2013), p. 260; Oliver Richmond and Roger Mac Ginty, 'Where now for the critique of the liberal peace?' Cooperation and Conflict, published online, 20 August 2014, p. 7.)

${ }^{18}$ Acharya, 'Dialogue and Discovery'. 
or historical experiences into the construction of new theories. ${ }^{19}$ The IR literature now contains numerous attempts to develop new concepts or theories through national or regional schools in BRIC states. ${ }^{20}$ Although Acharya was attentive to the dangers of parochialism wrought by an increasingly regional perspective, it is difficult to see how competing particularisms could be overcome and a genuinely global account of world politics be achieved. ${ }^{21}$

In sum, the promotion of 'non-Western' IR, while commendable in its intentions, has several problems. First, it may lead to a dangerous relativism whereby national schools become incommensurable with one another and no global dialogue is possible. Ling hints at this possibility with her elaboration of a Daoist approach to world politics, since the Chinese philosophy has no referents in Western discourse. ${ }^{22}$ How could global problems such as climate change or economic inequality be discussed at the international level - let alone addressed - without a unifying ontology of world politics? As Vasilaki argues,

IR - or any other field for that matter - is not getting post-Westernised or decolonised, and in that sense less hierarchical, by simply opening an intellectual space where more non-Western views can be aired (pluralism) or because various forms of particularisms (local or cultural IR) are elevated into universalisms'. ${ }^{23}$

Second, the concept 'non-Western' relies on problematic binary thinking that does not reflect the nature of 'West' and 'non-West' as mutually constitutive subjectivities over history. As Bilgin has pointed out, "Western" and "non-Western" dynamics as well as their interpretations have, over the years, clashed and fused in far too many different ways' for mutually exclusive categories to be reflective of reality. ${ }^{24}$ Further, when framed in these binary terms, IR is about Us and Them; as such, it remains a self-referential project. Third, the creation of national or regional schools of IR has the potential to lead to a crass ethno-centrism, which associates certain types of thinking about and doing politics with the cultural traits of specific geographical regions. ${ }^{25}$ It is important not to assume or overstate the influence of, say, the Qing era tributary system on contemporary Chinese foreign policy or Ghandian pacifism on Indian contemporary international behaviour. Numerous studies have emphasised rising powers' 'pragmatic' approach to international affairs, rather than behaviour fuelled by any alternative ideology. ${ }^{26}$ Fourth, the attempt to 'democratise' the field by requiring that 'non-Western' academia conduct its own version of IR does not dislodge Western hegemony as it forces the non-Western academy into the permanently subordinate position of playing 'catch-up'.

Acharya's recent work considers these criticisms and now casts the empirical and theoretical shift in post-Western terms. Joining Ling and Bilgin in an International Studies Association presidential special issue of International Studies Review on Global IR, Acharya argues against the current state of the field

\footnotetext{
${ }^{19}$ Acharya and Buzan, 'Why is there no non-Western International Relations Theory'?

${ }^{20}$ Makarychev and Morozov, 'Is “non-Western” Theory Possible?'; Qin, 'Why is there no Chinese International Relations Theory?'; Tsyagnakov and Tsyagankov, 'National Ideology and IR Theory'; Shani, 'Towards a postWestern IR'.

${ }^{21}$ Acharya, 'Dialogue and Discovery'; Amitav Acharya, 'Global International Relations and Regional Worlds: A New Agenda for International Studies’, International Studies Quarterly 58 (2014), pp. 647-659.

${ }^{22}$ Ling, 'Worlds beyond Westphalia', p.7

${ }^{23}$ Vasilaki, 'Provincialising IR?'

${ }^{24}$ Pinar Bilgin, 'Thinking Past “Western” IR', Third World Quarterly 29:1 (2008), pp. 5-23.

${ }^{25}$ Naeem Inayatullah and David Blaney, International Relations and the Problem of Difference, (London: Routledge, 2004), pp. 12.

${ }^{26}$ Navnita Chadha Behera, 'Re-imagining IR in India', International Relations of the Asia-Pacific 7 (2007), pp. 341-368; Robert Sutter, Chinese Foreign Relations: Power and Policy since the Cold War, Third Edition, (Plymouth: Rowman and Littlefield, 2012); Ivan Campbell, Thomas Wheeler, Larry Attree, Dell Marie Butler and Bernado Mariani, China and Conflict Affected States: Between Principle and Pragmatism, Saferworld Report 2012; Shaun Breslin, 'China and the Global Order: Signalling Threat or Friendship?' International Affairs 89:3 (2013), pp. 615-634; Amrita Narlikar, 'India Rising: Responsible to Whom?' International Affairs, $89: 3$ (2013), pp. 595-614.
} 
with Western scholars 'largely doing the theoretical work' while non-Western regional specialists provide the 'raw data' ${ }^{27} \mathrm{He}$ challenges a second generation of scholars seeking to develop a Global IR in post-Western terms, 'to demonstrate that concepts and theories derived from the non-Western or Global South contexts can also apply beyond that specific national or regional context from which they are initially derived' ${ }^{28}$ This article takes up his challenge. Hurrell states, in the ISR edition's forum, that 'the crucial first step is to recognize that dominant concepts and ideas never travel unproblematically'. ${ }^{29}$ Novel concepts may be required but so is a recognition that all concepts in global IR are 'travelling concepts'; many have travelled through colonised worlds and (post)colonial times. ${ }^{30}$

This point is demonstrated in some of historical IR of the non-West, particularly of East Asia. ${ }^{31}$ Most of this literature suggests that there were in fact commensurable social and political processes occurring in early modern East Asia and Europe, which can be analysed in a common framework. ${ }^{32}$ Victoria TinBor Hui shows that similar domestic and international processes of governance were occurring around the same time in early modern Europe and Qin-era China, such as the emergence of territorially bound sovereign units, the development of bureaucracy and the concept of balance of power. ${ }^{33}$ In a similar vein, Andrew Philipps argues that the transformation of both Christendom and the Sinosphere were driven by a combination of similar domestic and external factors, including institutional decay, the emergence of anti-systemic ideologies and increases in violence. ${ }^{34}$ Alastair Johnson's study of Chinese military engagements with the Mongols during the Ming Dynasty suggests that they were not so different from European realpolitik of parabellum, a finding corroborated by Ji-Young Lee's study of the Qing-era tribute system. ${ }^{35}$ Taking an English School approach, Yongjin Zhang and Barry Buzan argue that the tribute system demonstrates the existence of a form of international society in East Asia since participation therein indicates acceptance of the structure and its mode of participation. ${ }^{36}$ Applying the English School to the Russian case, Filippo Costa Buranelli problematises the West/rest dichotomy by showing how Russia's defeat in the Crimean War compelled European international society to view the country as a 'non-Western' power, despite Russia's desire to conform to European standards of 'civilization'. ${ }^{37}$ Studies such as these suggest that concepts of world politics that can travel across cultures may be found through comparative historical analysis and appreciation of the common legacies of regional power asymmetries.

\footnotetext{
${ }^{27}$ Amitav Acharya, 'Advancing Global IR: Challenges, Contentions and Contributions', International Studies Review, 18:1 (2016), p. 5.

${ }^{28}$ Acharya, 'Advancing Global IR', p. 14.

${ }^{29}$ Andrew Hurrell, 'Beyond Critique? How to Study Global IR', International Studies Review, 18:1 (2016), p. 151.

${ }^{30}$ See Mieke Bal, Travelling Concepts in the Humanities: A Rough Guide, (Toronto: University of Toronto Press, 2002); Michael C. Frank, 'Imaginative Geography as a Travelling Concept: Foucault, Saïd and the Spatial Turn', European Journal of English Studies, 13:1 (2009), pp. 61-77.

${ }^{31}$ The authors wish to thank an anonymous reviewer for directing them to this literature.

${ }^{32}$ Not all scholars of historical IR adhere to this view. For instance, David Kang contrasts the Chinese tribute system, which ensured five centuries of peaceful international relations with Korea, Japan and Vietnam through Confucian hierarchical relations, with the Westphalian system that developed in Europe and relied on balance of power between formally equal, sovereign entities. See David Kang, East Asia Before the West: Five Centuries of Trade and Tribute, (New York: Columbia University Press, 2010).

${ }^{33}$ Victoria Tin-Bor Hui, War and State Formation in Ancient China and Early Modern Europe, (New York: Cambridge University Press, 2005).

${ }^{34}$ Andrew Phillips, War, Religion and Empire: The Transformation of International Orders, (Cambridge: Cambridge University Press, 2010).

${ }^{35}$ Alastair Iain Johnston, Cultural Realism: Strategic Culture and Grand Strategy in Ming China, (Princeton, NJ: Princeton University Press, 1995); Ji-Young Lee, China's Hegemony: Four Hundred Years of East Asian Domination, (New York: Columbia University Press, 2016).

${ }^{36}$ Zhang Yongjin and Barry Buzan, 'The Tributary System as International Society in Theory and Practice', Chinese Journal of International Politics, 5:1 (2012).

${ }^{37}$ Filippo Costa Buranelli, 'Knockin' on Heaven's Door: Russia, Central Asia and the Mediated Expansion of International Society', Millennium: Journal of International Studies, 42:3 (2014), pp. 817-836. A similar point is made by Iver B. Neumann and Vincent Pouliot, 'Untimely Russia: Hysteresis in Russian-Western Relations over the Past Millennium', Security Studies, 20:1 (2011), pp. 105-137.
} 
We situate ourselves alongside, first, those who contend that it is possible to locate and employ concepts that travel across cultures and époques, and, second, those who argue that the post-Western puzzle must be considered alongside the postcolonial question in the study of IR. A postcolonially informed postWestern IR, therefore, entails the study of the global and dialectical condition of the relative decline of Western powers, observable in practice and interpreted through discourse, not their replacement by or competition with non-Western alternatives. This requires recognition of the discipline's colonial origins and the requirement to question ethnocentric or ahistorical usages of concepts of international order, hegemony and even 'emerging' or 'rising' powers. ${ }^{38}$ While, as we demonstrate below, postcolonial and post-Western international relations are not identical, what they share is an acknowledgement of both the interconnections between actors, institutions and discourses in different regions, and the international power asymmetries that have produced (and continue to produce) global hierarchies. Adherents to this approach self-consciously seek new categories that 'foreground human experiences of violence and poverty, political action and cultural renewal, in spaces not confined by nation-state boundaries, ${ }^{39}$ which may be drawn from Western or non-Western scholarship. ${ }^{40}$ Their value is found not in their ascribed origin but in their revealing of the extant power relations patterned into global politics and practiced by amalgams of Western and Eastern, Northern and Southern actors. The following section elaborates two concepts that might assist us to disentangle postcolonial and postWestern international relations - Bhabha's 'mimicry' (expanded, following Ling, to comprise both 'formal' and 'substantive' aspects) and Scott's 'mētis'.

\section{Mimicry and Mētis: towards a postcolonial approach to post-Western IR}

Like the effects of the coloniser on the colonised, post-Western international relations exhibit countervailing tendencies - assimilation with, hybridisation of, and resistance to the existing discourses, practices and institutions of global politics. Taken together, mimicry and mêtis enable us to probe these tendencies. They foreground the ways in which postcolonial (and post-Western) subjects discursively represent and practically realise relations with former and prospective imperial masters (or regional/global hegemons), both at the official level or public transcript, in the case of mimicry, and at an unofficial level or hidden transcript, in the case of mêtis.

Mimicry as a form of agency under colonial conditions was originally conceptualised by cultural theorist Homi K. Bhabha. For Bhabha, colonial mimicry refers to 'the desire for a reformed, recognizable Other, as a subject of a difference which is almost the same, but not quite' and its practices constitute colonial 'traditions of trompe-l'œil, irony, mimicry and repetition' between imperial Self and colonised Other. ${ }^{41}$ An exploration of colonial mimicry as a form of agency begins with the assumption that 'the place of difference and otherness, or the space of the adversarial... is never entirely on the outside or implacably oppositional'. ${ }^{42}$ Thus, in contrast to out-right resistance, mimicry challenges the colonial power base of the hegemon or coloniser by appropriating and subverting its discourses or behaviour. Although it implies outward and formal adherence, colonial mimicry enables subordinate actors subtly to shape the agenda of dominant actors, thereby revealing how the latter are in fact dependent on the former.

The concept of mimicry has hitherto been systematically employed in International Relations in two main ways. The first situates it within the norm-diffusion literature and conceives of mimicry as a broadly consensual activity: a step towards socialisation into the international system. ${ }^{43}$ Since this group

\footnotetext{
${ }^{38}$ Branwen Gruffydd Jones, Decolonizing International Relations, (London: Rowman and Littlefield, 2006).

${ }^{39}$ Lucy Taylor, 'Decolonizing International Relations: Perspectives from Latin America', International Studies Review 14 (2012), pp. 386-400.

${ }^{40}$ Ling, 'Worlds beyond Westphalia', p. 556.

${ }^{41}$ Bhabha, The Location of Culture, p. 122.

${ }^{42}$ Homi Bhabha, 'Signs Taken for Wonders: Questions of ambivalence and authority under a tree outside Delhi, May 1817’, Critical Inquiry 12 (1985).

43 Alasdair Ian Johnston, Social States: China in International Institutions 1980-2000, (Princeton: Princeton University Press, 2008); Alan Collins, 'Norm Diffusion and ASEAN's Adoption and Adaption of Global
} 
does not conceive of mimicry as a necessarily postcolonial or post-Western activity, it is of little relevance to our study. The second approach draws explicitly on Bhabha to explore the ways in which states are challenging the hegemony of Western 'international' practices and institutions. Bilgin considers India's development of the nuclear bomb, Turkey's policy of secularisation in the 1920s and Asia's integration into the Western-led international society of states, in each case offering an explanation of their 'mimicry' of Western statehood that also implies a subversion/tailoring of it to suit their postcolonial realities. ${ }^{44}$ In the context of IPE, John Hobson and Leonard Seabrooke have developed the concept of 'mimetic challenge', which refers to the ways in which 'everyday actors adopt the discourse and/or characteristics of the dominant to cloak their resistance-challenges to the legitimacy of the dominant' ${ }^{45}$

Most importantly for the present study, L.H.M. Ling has distinguished two levels of mimicry: 'formal mimicry' comprises superficial emulation, while 'substantive mimicry' refers to a deeper level of engagement that produces a hybridised set of practices and identities. ${ }^{46}$ Both levels of mimicry destabilise colonial relations, but formal mimicry invites 'amusement, tolerance, even encouragement' while substantive mimicry elicits a disciplinary action, since the postcolonial subject is now competing with the hegemon. ${ }^{47}$ Ling's two conceptualisations present mimicry as a means of reclaiming politics on the part of the subordinate; however, substantive mimicry represents well-established postcolonial relations while 'formal mimicry' is merely emergent. In our view, these levels of mimicry constitute a fruitful avenue to explore post-Western international relations because they require an understanding of both the Western/imperial projects themselves and the extents to which subordinates have the power to erode and undermine them. We employ Ling's distinction in our analysis below.

However, a focus on types of mimicry alone is insufficient to capture the variety of cultural, economic and political actions that compose post-Western international politics. As scholars of social movements have demonstrated, citizens' campaigns, grassroots organisations and other less formal groups have a considerable effect on global politics. ${ }^{48}$ Thus, as formal and substantive mimicries capture postcolonial elite discourse and practices in public, James C. Scott's conception of mêtis concerns the vernacular moral economy. For Scott, 'public transcripts' of conformity and unity - such as those conceptualised in mimicry - offer 'an indifferent guide to the opinion of subordinates' ${ }^{49}$ Thus, he introduces the idea of a 'hidden transcript' that is 'beyond direct observation by powerholders' ${ }^{50}$ A hidden, alternative reality - 'an extensive offstage social existence' - is sustained by what Scott calls 'the infrapolitics of subordinate groups' ${ }^{51}$ His Seeing Like a State highlights how attempts to impose 'high-modernist' ideologies - from Soviet collectivism to Brazilian city-planning - onto various societies have been defeated by 'cunning' and 'practical knowledge' that he denotes with the Greek term mêtis - a quality attributed to the wily Odysseus in the Trojan wars. ${ }^{52}$ Mētis, in Scott's usage is synonymous with 'common sense, experience, a knack', and is best observed at the local level, in craftsmanship and schemes of corruption, in attempts to maintain virtue and attempts to exploit it.

HIV/AIDS Norms', International Relations of the Asia-Pacific, 13 (2013); See Seng Tan, 'Herding Cats: The Role of Persuasion in Political Change and Continuity in the Association of South-East Asian Nations', International Relations of the Asia-Pacific, 13:2 (2013), pp. 233-265; Peter Ferdinand and Jue Wang, 'China and the IMF: From Mimicry to Pragmatic International Institutional Pluralism', International Affairs, 89:4 (2013), pp. 895-910.

${ }^{44}$ Bilgin, 'Thinking past "Western” IR'.

${ }^{45}$ John Hobson and Leonard Seabrooke, 'Chapter 1: Everyday IPE: Revealing Everyday Forms of Change in the World Economy' in John Hobson and Leonard Seabrooke (eds.) Everyday Politics of the World Economy, (Cambridge: Cambridge University Press, 2007), p. 17.

${ }^{46}$ Ling in Chowdhry and Nair (eds.), Power, Postcolonialism and International Relations.

${ }^{47}$ Ibid., p. 117. See also L.H.M. Ling, Postcolonial International Relations: Conquest and Desire Between Asia and the West (London: Palgrave, 2002); Ling, Huang and Chen, 'Subaltern Straits'.

${ }^{48}$ David West, Social Movements in Global Politics, (Cambridge: Polity Press, 2013).

${ }^{49}$ James C. Scott, Domination and the Arts of Resistance: Hidden Transcripts, (New Haven: Yale, 1990), p. 3.

50 Ibid., p. 4.

${ }^{51}$ Ibid., p. 21.

${ }^{52}$ Scott, Seeing Like a State, p. 6, 313. 
Scott is widely cited across disciplines, especially in Asian Studies, but his use in International Relations has, surprisingly, been limited. Moreover, his relevance to postcolonial analysis is questionable given his general conception of the state as a modernist institution. Some justification of his deployment here is therefore required. Sabaratnam defends Scott's work as consistent with anti-colonial thinking, insofar as it 'gives us a handle on how to think about the history of political rule that does not naturalise authority but points to its location in contested relations' ${ }^{53}$ Philips makes a similar argument, from the perspective of Global History and in a manner consistent with Scott's mētis, that 'European colonialism was the product of extensive collaboration with local intermediaries'. ${ }^{54}$ It was therefore changed and adapted by the cunning and know-how of native elites with whom it collaborated. This is what Acharya denotes as 'localization' 55 and Philips similarly identifies as 'customization'. ${ }^{56}$ 'Indigenous material, institutional, and normative resources,' Philips notes, 'provided the raw materials out of which colonial hierarchies were constructed' ${ }^{57}$ Like mimicry, mētis works both for and against imperial practices. It works for neo-colonial orders in that it is functional to the continuance of power relations. As Scott says, high modernism is always parasitic upon mētis, without which imperial projects would be powerless at the micro-level. However, mētis works against imperial practices and for the emergence of postcolonial hybridities in the self-consciousness it protects and the resources it re-appropriates from empire. ${ }^{58}$ This is not to say that there is something essentially democratic in mētis, which may work either for hierarchy or for anarchy.

Where mētis has been used in IR has been in the analysis of international intervention. Whilst lacking the explicit authoritarianism of many of Scott's examples, national and international statebuilding projects nevertheless exhibit many high-modernist features and are routinely defeated or diverted - or, alternatively, made to work in specific contexts - by practical knowledge. ${ }^{59}$ The cognate concept of 'tactics' in the work of Michel de Certeau has also been deployed widely by critical scholars of statebuilding. ${ }^{60}$ Such projects frequently only work if the power of the central state is instantiated in local patron-client relations at the periphery and national economies of resource capture are supplemented by localized asset grabs and livelihoods strategies. ${ }^{61}$ It should be no surprise that mētis is a defining characteristic of subaltern behaviour in former socialist states where, as the popular phrase goes, 'we pretend to work and they pretend to pay us'.

Together, mimicry and mētis reflect the postcolonial condition of East-West mimetic rivalry and elite networks of rent-seeking. They suggest that colonised, post-colonial and subordinate actors are not passive receptors of imperial/neo-imperial projects, but are able to disrupt and appropriate those projects for their own ends, both at the institutional and everyday levels. Bhavna Dave's 'four crucial insights of postcolonial and subaltern theory' invoke the dynamics of mimicry and mētis. Mimicry is visible in

\footnotetext{
${ }^{53}$ Meera Sabaratnam, Rethinking the liberal peace: anti-colonial thought and post-war intervention in Mozambique, PhD dissertation, London School of Economics (2011), p. 156.

${ }^{54}$ Andrew Philips, 'Global IR Meets Global History: Sovereignty, Modernity and the International System's Expansion into the Indian Ocean', International Studies Review 18 (2016), p. 64.

${ }^{55}$ Amitav Acharya, 'How Ideas Spread: Whose Norms Matter? Norm Localization and Institutional Change in

Asian Regionalism', International Organization 58:2 (2004), pp. 239-75.

${ }^{56}$ Philips, 'Global IR Meets Global History'.

${ }^{57}$ Ibid.

${ }^{58}$ Scott, Seeing Like a State, p. 340.

${ }^{59}$ John Heathershaw, Post-Conflict Tajikistan: the politics of peacebuilding and the emergence of legitimate order, (Abingdon: Routledge, 2009); Sabaratnam, Rethinking the Liberal Peace; Marta Iñiguez de Heredia, Everyday Resistance in Post-Conflict Statebuilding: The Case of Eastern Democratic Republic of Congo, $\mathrm{PhD}$ Dissertation, London School of Economics and Political Science (2013).

${ }^{60}$ Michel de Certeau, The Practice of Everyday Life, trans. Steven Rendall, (University of California Press, Berkeley, 1984); Daria Isachenko, The Making of Informal States: Statebuilding in Northern Cyprus and Transdniestria, (Basingstoke: Palgrave-MacMillan, 2012); Alex Veit, Intervention as indirect rule: civil war and statebuilding in the Democratic Republic of Congo, (Frankfurt: Campus Verlag, 2010).

${ }^{61}$ Beril Bliesemann de Guevara and Florian Kühn, 'On Afghan Footbaths and Sacred Cows in Kosovo: Urban Legends of Intervention', Peacebuilding 3:1 (2013), pp. 17-35.
} 
'a new ontology and vocabulary of nation and statehood' and the fact that independent statehood is not the culmination of nationhood but 'only a starting point' - one bequeathed by Soviet borders and institutions. ${ }^{62}$ Mêtis is present in the 'collaboration of native elites with the colonial order' and 'the contestations between [elite and popular] domains in both colonial and postcolonial contexts'. ${ }^{63}$ In this light, the relationship between mimicry and mêtis is not so much dialectical as symbiotic. The following two sections explore the extent to which these two concepts can reveal postcolonial aspects of postWestern international relations at global and regional levels.

\section{Post-Soviet Russia: from pro-Western to post-Western}

Contemporary Russia may be the post-Western power par excellence, with its leaders vociferously arguing against the Western-led international order in recent years, ${ }^{64}$ after centuries of domestic equivocation between Europhile (or 'Westernising') and Slavophile elements. ${ }^{65}$ Whether current global power shifts away from the West towards Asia will set Russia's severely marginalised Westernising forces in terminal decline remains to be seen, but for now relations between Russia and the West are at an historic low, while Russian co-operation with non-Western powers such as China and Iran is growing. However, Russia's post-Western status should not be confused with the position of its Eurasianist scholars, who have been 'using a culturalist terminology to argue that Russia has a Eurasian essence ${ }^{66}$ In contrast to such normative essentialism, which espouses a set of timeless, inherent, cultural attributes that Russia should develop and inculcate, 'post-Western' refers to a temporally contingent set of relations between Russia (or indeed any other power) and the Western-led international order, which, as we show below, involve shifts from formal to substantive mimicry. This section presents Russia as a post-Western power by summarising the decline of its formal mimicry of Western discourses and practices before showing how it employs postcolonial practices of substantive mimicry and mētis in order to challenge and undermine Western global dominance.

In the aftermath of Soviet collapse, the Westernisation of Russia seemed practically inevitable, as the country's leadership professed unreserved support for the Western-oriented reform agenda. Foreign minister Andrey Kozyrev described Russia and the West as 'natural friends and eventual allies', ${ }^{67}$ liberal reformers were in charge of the economy, and Boris Yeltsin presided over a national strategy that prioritised integration with the West even above the countries of the former Soviet bloc. ${ }^{68}$ This orientation towards the West can be conceptualised as formal mimicry, whereby, following Ling, 'a country without an indigenous liberal tradition... adopts an imposed or borrowed liberal ideology of limited state and unfettered market', which remains 'dichotomised, superficial, contradictory and forever emulative'. ${ }^{69}$ Indeed, domestic economic reforms did not progress in the way the Russian democrats envisaged. Advisers at the IMF and the US treasury were quick to advocate principles of price liberalisation and privatisation, but did not attempt to build the social institutions that would support these mechanisms and ensure they could operate under popular control. ${ }^{70}$ Internationally, the expansion of NATO into Eastern Europe during the mid-1990s appeared to demonstrate to Russia that

\footnotetext{
${ }^{62}$ Bhavna Dave, Kazakhstan: Ethnicity, Language and Power, (Abingdon: Routledge, 2007), p. 23-24.

${ }^{63}$ Ibid., p. 24.

${ }^{64}$ In February 2017, Russian Foreign Minister, Sergei Lavrov explicitly called for a 'post-West world order' at the Munich Security Conference; whether this discourse will be mirrored in practice over the long term remains to be seen. See 'Foreign Minister Sergey Lavrov's address and answers to questions at the 53rd Munich Security Conference, Munich, February 18, 2017', The Ministry of Foreign Affairs of the Russian Federation, 18 February 2017. Available at: $\mathrm{http}: / / \mathrm{www} . \mathrm{mid} . \mathrm{ru} / \mathrm{en} / \mathrm{press}$ service/minister_speeches//asset publisher/7OvQR5KJWVmR/content/id/2648249.

${ }^{65}$ Iver Neumann, Russia and the idea of Europe (Abingdon: Routledge, 1996).

${ }^{66}$ Marlene Laruelle, Russian Eurasianism: An Ideology of Empire, (Washington, D.C.: Woodrow Wilson Center Press, 2008), pp. 8. See also Dmitry Shlapentokh, Dmitry, "Dugin Eurasianism: A Window on the Minds of the Russian Elite or an Intellectual Ploy?" Studies in East European Thought 59:3 (2007), pp. 215-36.

${ }^{67}$ Andrei Kozyrev, 'The Lagging Partnership: In Search of a Joint Strategy', Foreign Affairs, May/June 1994.

${ }^{68}$ Andrei Tsygankov, Russia's Foreign Policy: Change and Continuity in National Identity, Third Edition, (Lanham, MA: Rowman and Littlefield, 2013), p. 63.

${ }^{69}$ Ling in Chowdhry and Nair (eds), Power in a Postcolonial World, p. 116.

${ }^{70}$ Joseph Stiglitz, Globalization and its Discontents, (New York: W.W. Norton and Company, 2002).
} 
the West considered its Cold War-era instruments of defence still necessary. The West's abandonment of Russia during this reform period has been described as 'a folly comparable with that of Georges Clemenceau at Versailles or Neville Chamberlain at Munich'. ${ }^{71}$ Already in 1992, Kozyrev was forced to announce the end of the "honeymoon period" with the West and, in 1995, his replacement with Yevgeny Primakov completed the shift away from a formally pro-Western orientation and the move towards Russia as a 'Eurasian' power with aspirations to Great Power status. ${ }^{72}$

From the 2000s onwards, Russian policy continued to distance itself from West, driven by fears of domestic regime change via Western-funded NGOs (the notorious 'Colour Revolutions') and the relentless eastward expansion of NATO. ${ }^{73}$ In 2008, Russia's six-day war with Georgia demonstrated that it would not tolerate NATO encroachment in its 'near abroad' and would be prepared to challenge the European security architecture that had progressively marginalised Russia since Soviet collapse. Likewise, the annexation of Crimea in 2014 and the ongoing crisis in Syria have both demonstrated the extents to which Russia is prepared to go in order to counter what it perceives as Western attempts at domestic regime change.$^{74}$ Russia's military conquests of the last decade appear to have demonstrated Thakur's assertion that 'Westerners have lost their previous capacity to set standards and rules of behaviour for the world'. ${ }^{75}$

Despite Russia's ostensibly anti-Western stance, some scholars have emphasised its continuing Eurocentrism. Viatcheslav Morozov highlights Russia's unique position in the international system that consists of 'a subaltern condition fraught with an imperial legacy'. ${ }^{76} \mathrm{He}$ uses Bhabha's formulation of the Master and Slave to illustrate how Russia simultaneously appropriates and resists Western norms and practices of global politics. 'While opposing the West', Morozov states, 'Russia nevertheless frames its own demands in the Western language of democracy' ${ }^{77}$ Similarly, Ayşe Zarakol argues that Russia has always been an outsider state, caught between attraction to and rejection of the Westerndominated international system. Particularly in the post-Soviet period, the on-going stigmatisation of Russia by the West as inferior fuelled its ostensible rejection of a pro-Western agenda. Yet, 'even at the peak of its post-defeat economic prowess, Russia has not been able to reject the norms of the international order this time round'. ${ }^{78}$ Although neither author refers to Russia in post-Western or postcolonial terms, these formulations nevertheless recall the spirit of substantive mimicry elaborated by Ling. We argue that the transformation of Russia to a post-Western power began as the formal mimicry of the West in the early 1990s transformed into substantive mimicry in the 2000s discussed below.

\section{Substantive Mimicry in Russia's Relations with the West}

Russia's post-Western status is discernible in its substantive mimicry of Western discourse and institutional formations, which produces hybridisations that expose the weaknesses of the Western liberal project and its perceived moral authority in the international system. In terms of discourse, Russia has employed Western concepts to shift power away from the West in attempts to build a multi-polar world order. Vladislav Surkov's articulation of 'sovereign democracy' aimed both to provide a legitimating concept for Putin's government and to guarantee Russia's independence in a globalising

\footnotetext{
${ }^{71}$ Anders Aslund, 'Revisiting the End of the Soviet Union', Problems of Post-Communism, 58 (2011), p 4-5.

72 Tsygankov, Russia's Foreign Policy, p. 69.

${ }^{73}$ See Gerard Toal, Near Abroad: Putin, the West and the Contest over Ukraine and the Caucasus, (Oxford: Oxford University Press, 2017), p. 5-7.

${ }^{74}$ Richard Sakwa, Frontline Ukraine: Crisis in the Borderlands, (London: I.B. Taurus, 2014); Roy Allison, 'Russia and Syria: Explaining Alignment with a Regime in Crisis', International Affairs, 89:4 (2013), pp. 795 823.

75 Ramesh Thakur, 'How Representative are BRICS' Third World Quarterly, 35:10 (2014), pp. 1791-1808.

${ }^{76}$ Viatcheslav Morozov, Russia's Postcolonial identity: A Subaltern Empire in a Eurocentric World, (London: Palgrave Macmillan, 2015), p. 103.

77 Ibid., p.23.

${ }^{78}$ Ayse Zarakol, After Defeat: How the East Learned to Live with the West, (Cambridge: Cambridge University Press, 2010), p. 238.
} 
international system. ${ }^{79}$ In the cases of the Russia-Georgia War, the Russian war in Ukraine and the ongoing Russian intervention in Syria, the Western concept 'responsibility to protect' has been invoked to justify military activities that diverged from Western norms and challenged Western power. ${ }^{80}$ Similarly, Russia has mimicked Western cross-national human rights rankings by producing their own document showcasing Western countries' domestic human rights abuses. ${ }^{81}$ This mimicry not only serves to provide a legitimating narrative for Russian activities that is difficult for the West to criticise, but its use in situations that challenge the Western normative order also exposes the latter's inconsistencies.

In terms of institution building, Russia substantively mimics Western political institutions at domestic and international levels. At the domestic level, the Russian state Duma resembles Western parliaments in form, but in practice has become a rubber-stamp body for the executive and is populated by government-approved parties that 'mimic opposition parties' by channelling votes away from genuine opposition. ${ }^{82}$ This system enables the Russian 'party of power', United Russia, to retain dominance while rebuffing Western criticisms that Russia is not 'democratic'. At the international level, Russia has instigated the creation of the Eurasian Economic Union, which comprises five former Soviet states and is modelled on the regional integrative principles of the European Union. ${ }^{83}$ According to Lilia Shevtsova, one of the explicit aims of this organisation is to 'counterbalance the EU'. ${ }^{84}$ In applying these institutional forms to non-democratic contexts, this substantive mimicry serves subtly to challenge the notion that Western institutional models are universalisable.

Our interview respondents bear witness to this shift from formal to substantive mimicry in Russia's relationship with the West. Interviewees routinely referred to Russian initiatives as shadows of Western practices and institutions. The EEU was compared to the European Union, the CSTO to NATO, and the CSTO's rapid reaction force to its NATO equivalent. ${ }^{85}$ The obvious conclusion that Russians, in the words of a journalist in Dushanbe, 'copy the Western experience' is tempered by caveats on how formal post-Western mimicry works in substantively post-Soviet terms. ${ }^{86}$ In total, interviewees made 42 references to Russian-Western dynamics in Central Asia but a further 67 to post-Soviet remnants of Soviet practices/institutions (see figure 1).

\section{Metis in Russia's Relations with the West}

Although mētis is present in any form of substantive social relations that extend beyond formal process, its nature as a necessarily 'hidden' transcript makes it difficult to observe in practice. Thus, mētis in Russian foreign policy was hinted at by interviewees in Moscow rather than made explicit, which indicates a methodological weakness in this study as (unlike our earlier work on Russia and Central Asia ${ }^{87}$ ) it did not deploy ethnographic methods. In the post-Soviet space, it is commonplace to speak in code about the informalities, inadvertent effects and corruption of formal institutions. In discussing

\footnotetext{
${ }^{79}$ Andrei Okara, 'Sovereign Democracy: A New Russian Idea or a PR Project?' Russia in Global Affairs, 5:3 (2007).

${ }^{80}$ Derek Averre and Lance Davies, 'Russia, Humanitarian Intervention and the Responsibility to Protect: The Case of Syria', International Affairs, 91:4 (2015), pp. 813-834; Asmus, A Little War that Shook the World.

${ }^{81}$ Tyler Roylance, 'Russia Spoofs the Human Rights Report', Freedom House, 3 January 2012. Available at: https://freedomhouse.org/blog/russia-spoofs-human-rights-report

${ }^{82}$ Hans Oversloot and Reuben Verheul, 'Managing Democracy: Political Parties and the State in Russia', Journal of Communist Studies and Opposition Politics, 22:3 (2006), p. 392.

${ }^{83}$ Rilka Dragnaeva and Kataryna Wolczuk, 'Russia, the Eurasian Customs Union and the EU: Cooperation, Stagnation or Rivalry?' Chatham House Briefing Paper, Russia and Eurasia Programme (2012), p. 2.

${ }^{84}$ Lilia Shevtsova, 'Forward to the Past in Russia', Journal of Democracy, 26:2 (2015), p. 26.

${ }^{85}$ Interviews: representative of the Association of Politologists Kyrgyzstan, Nov 2013; Institute of International Economy and International Relations, RAS, Moscow, December 2013; Centre of Political Research; Presidium of Russian Academy of Sciences, Moscow, July 2013.

${ }^{86}$ Interview, editor of political magazine, Dushanbe, November 2013.

${ }^{87}$ See, for example, John Heathershaw, 'The global performance state: a reconsideration of the Central Asian "weak state"' in Madeleine Reeves, Johan Rasanayagam and Beyer J (eds) Performing Politics in Central Asia: Ethnographies of the State, (Bloomington: Indiana University Press, 2013), pp. 39-61.
} 
the EEU, one Russian scholar pointed to its malfunctions: 'What is this body? Does it really implement anyone's will? At least for me, it is difficult to say that it implements Russia's will. This body is unable to control its activities. ${ }^{98}$

Central Asian interviewees noted Russia's lack of an explicit strategy for Central Asia and its shortterm approach. A human rights activist in Bishkek contrasted US and Russian approaches as follows: 'If the Americans start making friends with someone from the cradle and walk with this person till the end [of his life], moulding his consciousness and his environment, then Russians form these relations with a sudden lunge [naskokom] '. ${ }^{89}$ One Kyrgyz journalist working for a Russian media outlet defined the 'Russian approach' as according to an 'administrative logic'. 'You find someone', he noted, 'you talk to that person, achieve mutual understanding, but where and in what form your proposal will move on is a big question. The Russian approach constitutes an administrative pyramid'. ${ }^{90}$ Such administrative pyramids are familiar to elites who grew up in the late-Soviet period with its bureaucratic hypertrophy and 'cynical reason'. ${ }^{1}$

These findings suggest that Russia is a 'rising' power chiefly in its substantive post-Western mimicry, though perhaps also in its post-Soviet mētis, through which it is able to re-appropriate Western discourses and institutional forms and thereby challenge and subvert Western dominance. While mētis in this case shows us how local officials might subvert new projects such as the EEU, it is practices of substantive mimicry that are most clearly associated with the emergence of the post-Western. Substantive mimicry serves to delegitimise the existing order through the attachment of new meanings to old concepts and practices of international relations. In this way, Russia (though by no means only Russia) is helping to bring about a post-Western world order.

\begin{tabular}{|l|l|l|}
\hline Table 1: Summary of themes identified in analysis & $\begin{array}{l}\text { Number of } \\
\text { interviewees citing } \\
\text { (out of 38) }\end{array}$ & $\begin{array}{l}\text { Total number of } \\
\text { references in text }\end{array}$ \\
\hline Major descriptive themes (cited by 10 or more & & \\
interviewees) & 24 & 67 \\
Post-Soviet remnants & 17 & 46 \\
Russian activities in Central Asia - general & 17 & 35 \\
Socialisation of Central Asia into Russian culture & 16 & 42 \\
Russia versus the West in Central Asia & 16 & 35 \\
China and Chinese activities in Central Asia & 12 & 19 \\
The Central Asian state & & \\
& & 57 \\
\hline Major evaluative and analytical themes (cited by 10 \\
or more interviewees) & 20 & 35 \\
Negative view of Russia & 17 & 42 \\
Positive view of Russia & 17 & 47 \\
Withdrawal of Russia from Central Asia & 16 & 32 \\
Mimicry of Russia in Central Asia & 14 & 22 \\
Russia as centre, Central Asia as periphery & 13 & 22 \\
Growing role of Russia in Central Asia & 10 & \\
Metis of Russia in Central Asia & & \\
&
\end{tabular}

\footnotetext{
${ }^{88}$ Interview, Russian academic, Moscow, Moscow, June 2013.

${ }^{89}$ Interview, Human Rights activist, Bishkek, November 2013.

${ }^{90}$ Interview, Journalist, Bishkek, November 2013.

${ }^{91}$ Alexei Yurchak, Everything was Forever until it was No More, (Princeton: Princeton University Press, 2006).
} 


\section{Central Asia: a postcolonial, post-Western region?}

The Central Asian region exemplifies the convergence of postcolonial and post-Western international relations. First, it is a postcolonial region, having been colonised by the Russian Empire in the Eighteenth and Nineteenth Centuries. Second, it is a region with little, and decreasing, Western influence. This final section sets out Central Asia as a postcolonial post-Western space, before analysing the form and content of the practices of mimicry and mētis reported by interviewees.

Central Asia's postcolonial aspect is debated by modern historians in terms of whether the Soviet Union, as the successor to the Russian Empire in the region, was a colonial empire or a multinational modernising state. ${ }^{92}$ It is widely accepted that the USSR was a hybrid of the two as an 'affirmative action empire' or 'empire of nations' ${ }^{93}$ However, an increasing number of scholars of Central Asia analyse the region's Soviet history and its independence in colonial and post-colonial terms, including revealing the colonial aspects of specifically anti-colonial and internationalist Soviet strategies in Central Asia. ${ }^{94}$ There is surely no dispute that Central Asia was colonised by the Russian Empire in a manner largely consistent with the form and content of European imperial conquest. The important question therefore is not whether Central Asia is postcolonial, but when and how it is postcolonial. 'Post-imperial remnants' was the most common descriptive theme in the interviews with 24 interviewees making reference on 67 occasions. One Tajik journalist noted that Russia was resurging in Tajikistan, not due to genuine closeness or regional commonality but because 'as it turns out, it is very difficult to live without Russia'. ${ }^{95}$

In terms of Central Asia's post-Western status, Western influence has been receding since the waves of interventions for democratization, development and security assistance of the 1990s and early-2000s. Western normative engagement was unsuccessful in fomenting democratic transitions in the region, despite the formal mimicry of its constitutions and electoral processes and substantive adoption of financial liberalization. References to Western activities were rare among our interviewees (6 references by 5 interviewees) and therefore do not even appear in the table, in stark contrast to references to Russia ( 46 by 17) and secondarily China ( 35 by 16). Given our interviews were conducted by an ethnic Russian and specifically addressed Russian foreign policy this is hardly surprising. However, the fact that interviewees were almost six times more likely to pivot from Russia to statements about China than about the West is telling. Analytical and evaluative statements in our interview data mirrored this decline: the West was portrayed as distant, irrelevant and inactive, a fair-weather friend that would not assist in times of crisis. One respondent described the prospect of Western involvement in the region as 'just a beautiful idea' ${ }^{96}$ Further, where comparisons were made, the Western approach to conflict was seen as mired in bureaucracy and proceduralism, based on values considered alien to local populations. Russia, by contrast, was considered Central Asia's true partner, able to act as security guarantor and control the influence of other major powers. In the words of one respondent, 'Everybody

\footnotetext{
92 David Chioni Moore, 'Is the post- in Postcolonial the post- in Post-Soviet? Towards a Global Postcolonial Critique', PMLA, 116:1 (2001), pp. 111-128; Mark Beissinger, 'Soviet Empire as "Family Resemblance", Slavic Review, 65:2 (2006), pp. 294-303.

${ }^{93}$ Francine Hirsch, 'Toward an Empire of Nations: Border-Making and the Formation of Soviet National Identities', Russian Review 59: 2 (2000), pp. 201-226; Terry Martin, The Affirmative Action Empire: Nations and Nationalism in the Soviet Union, 1923-1939, (Ithaca, NY: Cornell University Press, 2001).

${ }^{94}$ Rahim Masov, Istoriya Topornovo Razdeleniya [History of an Axe-Like Delimitation], (Dushanbe: Irfon, 1991); Douglas Northrop, Veiled Empire: Gender and Power in Stalinist Central Asia, (Ithaca: Cornell UP, 2004); Laura Adams, 'Can We Apply Postcolonial Theory to Central Eurasia?', Central Eurasian Studies Review, 7:1 (2008), pp. 2-7; Botakoz Kassymbekova, 'Helpless imperialists: European state workers in Soviet Central Asia in the 1920s and 1930s', Central Asian Survey, 30:1 (2011), pp. 21-37; Dave, Kazakhstan; Malika Bohavidonova \& Artemy M. Kalinovksy, 'Internationalism and (Post)Colonialism: Central Asia and Soviet Development Paradigm’, unpublished conference paper, IMPERIAL REVERB: Exploring the Postcolonies of Communism, May 13-15, 2016, Princeton University.

${ }^{95}$ Interview, Tajik journalist, Khudjand, November 2013.

${ }^{96}$ Interview, former MP and Uzbek community leader, Bishkek, November 2013.
} 
knows that, as long as there is a Russian base here, the United States can't play any kind of big games here'. ${ }^{97}$ Others highlighted Russia's absolute power in the region: '[The President of Tajikistan Emomoli] Rahmon can't not make an agreement with Russia, he can't alienate Russia. Because Russia has its interests here. It can do anything here, including a coup d'état'. ${ }^{98}$

Accordingly, practices of mimicry and mētis in Central Asia rely heavily on the region's ambivalent relationship with Russia, trapped between nostalgia for what is remembered as the brotherly Soviet-era relationship and a growing nationalism that instead recalls a colonial, exploitative past. Core postcolonial themes are present in the responses of our interviewees. In particular, evaluative statements of mimicry ( 47 references by 16 interviewees), centre-periphery relations ( 32 by 14) and mētis ( 22 by 10 ) were identified in the transcripts (see table 1$)$. Negative ( 20 interviewees) and positive (17) views are both common with a majority favouring negative or suspicious views of Russia. Similarly, there is debate both over Russia's withdrawal compared to Soviet times (17) and its postSoviet resurgence (13). Many in the region feel caught between the deep socio-cultural ties that come with decades of socialisation into Russian cultural practices and a growing distaste for Russia as a political entity. This equivocal relationship between the subaltern and the hegemon breeds practices of formal mimicry and mêtis - on the one hand unable to reject neo-imperialistic projects outright, but on the other disinclined to support them wholeheartedly.

\section{Mimicry in Kyrgyz and Tajik Relations with Russia}

Like Russia's mimicry of the West, state-level mimicry of Russia in Kyrgyzstan and Tajikistan is evident in both institutions and discourses. Russian governmental organisational forms, such as the Duma, have been reproduced to varying degrees across the region, and Central Asian legislative discourses tend to re-articulate those of Russia. ${ }^{99}$ However, unlike Russia's substantive mimicry of Western discourses, which serve to undermine Western global hegemony, Kyrgyz and Tajik reproductions and rearticulations tend towards emulation. Mimicry thus tends to remain at the formal level, unable to re-appropriate the power of the former coloniser.

To consider first institutional mimicry, national parliaments mimic the form of the Russian duma. According to one respondent, "supposedly we have a parliament, but in reality, there are groups there who are lobbying for shadow flows [of money], and as a matter of fact, they are occupied with lobbying for their own businesses, and the mandate of an MP is there to give immunity.' ${ }^{100}$ Another respondent called Kyrgyzstan a 'pseudo-parliamentarian republic.' ${ }^{101}$ Once created, such institutions, since they are not embedded in within a developmental tradition or ensemble of pre-existing supporting institutions, invent their own national raison d'être. This echoes the way in which the Russian duma mimics Western parliamentary politics; however, unlike Russia, Central Asian states do not seek to subvert hegemonic discourses of appropriate domestic political organisation. The mimicry here is formal: it is a superficial emulation of the former imperial master and does not try to rebalance power relations or challenge prevailing norms.

Post-Soviet security agencies also retain links and patterns indicating something between deep cooperation and institutional isomorphism. One Dushanbe-based respondent stated, 'The state security and law enforcement agencies are just for show. They demonstrate the invented threat and then fight with it themselves. ${ }^{102}$ The deep institutional continuities and enduring relations between Central Asian state security agencies and Russia's internal and external security services is one of the main vectors of Russia's relations with its former colonial territories. Tajikistan and Uzbekistan in particular have

\footnotetext{
${ }^{97}$ Interview, head of Central Asian news agency, Khudjand, November 2013.

${ }^{98}$ Interview, Islamic Revival Party of Tajikistan, deputy leader, Dushanbe, November 2013.

${ }^{99}$ For an overview of Russian military and political engagement in Kyrgyzstan since 2010, see David Lewis

'Re-asserting Hegemony in Central Asia: Russian Policy in Post-2010 Kyrgyzstan, Comillas Journal of International Relations, 1:3 (2015), pp. 58-80.

${ }^{100}$ Interview, independent expert, Bishkek, November 2013.

${ }^{101}$ Interview, Russian Institute of Strategic Studies, Bishkek, November 2013.

${ }^{102}$ Interview, opposition party member, Dushanbe, November 2013.
} 
successfully prosecuted campaigns against their political enemies based in Russia by orchestrating arrests, detentions, illegal formal extraditions, informal renditions and disappearances with the direct connivance of the Russian security services. The CIS' Minsk Treaty provides some formal provision for such cooperation but informally it is eased by customary processes whereby human rights safeguards are disregarded. There are at least 18 public records of Uzbek and Tajik exiles subject to disappearance, rendition and assassination with the suspected connivance of the Russian security services between 2001 and 2016. ${ }^{103}$ In some cases, Russia acted to arrest Central Asian exiles prior to the formal issues of a warrant by the Central Asian security service.

Regarding discursive mimicry, conservative laws adopted in Russia travel quickly to Central Asia, with governments adopting their own, often more conservative, versions. For example, the Russian so-called Foreign Agents law of July 2012, which requires NGOs receiving foreign funding and conducting 'political activities' to register as 'foreign agents' with the Ministry of Internal Affairs and label themselves as such on all their print and online materials. ${ }^{104}$ Similar laws have since been approved in Tajikistan and Kazakhstan, but a Kyrgyz version was unexpectedly rejected by the parliament at the bill's final reading in May 2016. In June 2013, Vladimir Putin signed the so-called 'Gay Propaganda Law' into the legal codex. This now infamous law, which claims to improve child protection, prohibited distribution of 'propaganda' about 'non-traditional sexual relationships' to minors. ${ }^{105}$ In January 2015, Kazakh deputies debated the addition of a similar clause to child protection legislation, though it was ultimately rejected amid fears it could damage the country's bid to host the 2022 Winter Olympics. ${ }^{106}$ In Kyrgyzstan, a more repressive version of the law, which would impose prison sentences instead of fines to people referring to homosexuality in public, is currently going through parliament. ${ }^{107}$

This formal mimicry works both for and against a relationship of colonial dependency with Russia. On one hand, the copying of parliamentary institutions and laws and the deep cooperation between security agencies demonstrate how Central Asian states - especially Kyrgyzstan and Tajikistan - continue the economic and security dependencies on Moscow. On the other hand, such mimicry does not imply either exclusive loyalty to Moscow, as it did in Soviet times, or adherence to a shared doctrine or ideology of governance. Formal postcolonial Central Asian mimicry therefore does not (yet) have the same disruptive potential as substantive post-Western Russian mimicry.

\section{Metis in Kyrgyz and Tajik Relations with Russia}

The practice of mètis demonstrates the practical limits of Russian power in Central Asia: at the level of discourse, mētis is visible in the use of local language to protect and make irreducible 'local knowledge'; at the level of practice, what is often termed corruption can also be seen as mêtis, since it is conducted through local clientelistic networks typically invisible to outsiders. As with Russia, our interview data on mētis is less strong given that it is often invisible without direct observation. However, unlike in Russia, in Central Asia it appeared to comprise a central aspect of everyday relations with the hegemon. Our respondents speak of mētis as they report the disintegration of Soviet institutional and ideological foundations that has left an environment fertile for the subversion of projects. As one respondent

\footnotetext{
${ }^{103}$ University of Exeter, Central Asian Political Exile database, version 1, November 2016, available at: http://blogs.exeter.ac.uk/excas/exiles/

${ }^{104}$ Rossiiskaya Gazeta, “Federal'nyi Zakon ot 20 iyulya 2012 g. N 121-F3 “O vnesenii izmenenii v otdel'nye zakonodatel'nye akty Rossiiskoi Federatsii v chasti regulirovaniya deyatel'nosti nekommercheskikh organizatsii, vypolnyayushchikh funktsii inostrannogo agenta", Rossiiskaya Gazeta, 23 July 2012, https://rg.ru/2012/07/23/nko-dok.html

${ }^{105}$ Rossiiskaya Gazeta, “Federal'nyi Zakon ot 29 iyunya 2013 g. N 135-F3 g. Moskva “O vnesenii izmenenii v stat'yu 5 Federal'nogo zakona “O zashchite detei ot informatsii, prichinyayoshchei vred ikh zdorov'yu i razvitiyu” i otdel'nye zakonodatel'nye atky Rossiiskoi Federatsii v tselyakh zashchity detei ot informatsii, propagandiruyushchei otritsanie traditsionnykh semeinykh tsennostei”, Rossiiskaya Gazeta, 2 July 2013, https://rg.ru/2013/06/30/deti-site-dok.html

${ }^{106}$ Joanna Lillis, 'Kazakhstan Strikes Down ‘Gay Propaganda’ Law After Olympics Outcry’, Eurasianet.org, 27th May 2015, http://www.eurasianet.org/node/73606.

${ }^{107}$ Franco Galdini, 'Kyrgyzstan's NGO and LGBT Crackdown', The Diplomat, 17 March 2016, http://thediplomat.com/2016/03/kyrgyzstans-ngo-and-lgbt-crackdown/
} 
lamented, 'contemporary Kyrgyz people don't work, there is no proletariat, agriculture is in decline, everybody is moving to the city, there is no work here. Clerks steal everything. Politicians do the same. The youth is either leaving [the country] or joining organized crime...' 108

While numerous respondents noted the slow decline of the Russian language in Central Asian public life as a regrettable loss, others saw it as a source of opportunity, as it enabled Central Asians to express discontent with Russia without being understood and chastised for it. 'I always say, guys, just understand one thing: the local people often lie in the Russian language..., one Central Asian respondent noted. 'For example, the migrants coming back are afraid to find fault with [scold/criticise] Russia in Russian - they are afraid that someone will spot them, register in some kind of book, black list - while in their own language it is possible.' ${ }^{109}$ Corroborating this, other respondents in Tajikistan noted that a critical discourse of Russia in the public sphere is completely absent. However, social media is used to publicise incidents of violence against Central Asian migrants in Russia: 'when something negative happens, it goes viral, becomes frantically shared, liked, tweeted, and these social networks become a powerful tool to influence public consciousness. ${ }^{110}$

What is often dismissed as corruption may also be understood as mētis. Order controls and trading regulations are frequently manipulated or even ignored by influential traders working on the re-export of goods of Chinese goods to Russia and other Central Asian states. It is the local knowledge of informal bureaucratic practices, and the subaltern agency of controlling those practices, that enables such manipulation to occur. 'They bring in 10 billion, but declare only 2 billion, while the other eight billion is being re-absorbed,' noted one interviewee. 'This practically is smuggling. This is what the whole [import/export] structure has been built on.' ${ }^{111}$ Such practices are reported as widespread in economic exchange with the former colonial power: 'Russian companies', reports another interviewee, 'faced the necessity to include into the budget money to be paid to the local elite.' The respondent, recalling the process of applying for Russian-funded grants, laments, 'While knowing that the project will cost 3-3.5 million roubles, we ask for 8 , we get 3.5 and the rest we must write off so that the people who give this money can keep it. And it's always like this.' ${ }^{112}$

Inevitably, this collaboration between native elites and former colonial power for personal and familial gains creates resentment from those excluded from the kick-backs offered by Russian contractors. This is the other side of mētis in Scott's analysis - that is, practical knowledge not just working for the maintenance of hierarchies through the completion of state projects but in its cunning containing the basis for the project's subversion. In Kyrgyzstan, the one country in Central Asia where a significant political opposition exists, these stories have become scandals that opponents of the government use to mobilize protests both in the capital and regions against the state. They become wedges that threaten the elite's control of its population. In recounting a story of a Russian-funded project in southern Kyrgyzstan one NGO worker in Osh remarked, they 'invest a lot of money, but there are few results. And the state too, they don't invest, they try to administrate, but there are few results from them too, because everything is kept within the structure (formalizovano) of the state'. ${ }^{113}$ Such corruption is so commonplace that some projects become more about the rent-seeking opportunities than about the strategic and infrastructural objectives. ${ }^{114}$

\footnotetext{
${ }^{108}$ Interview, journalist and member of strategic studies think tank, Bishkek, November 2013.

${ }^{109}$ Interview, member of public policy think tank, Bishkek, November 2013.

${ }^{110}$ Interview, university lecturer and former UNDP member, Bishkek, November 2013.

${ }^{111}$ Interview, independent expert, Bishkek, November 2013.

${ }^{112}$ Interview, journalist and member of strategic studies think tank, Bishkek, November 2013.

${ }^{113}$ Interview, head of Department for Social Research, National Academy of Sciences, Bishkek, November 2013.

114 There is a burgeoning academic literature on transnational corruption networks involving Central Asia. See: Alexander Cooley \& Jason Sharman 'Blurring the line between licit and illicit: transnational corruption networks in Central Asia and beyond', Central Asian Survey, Volume 34 (1), 2015, pp. 11-28; Alexander Cooley \& John Heathershaw, Dictators Without Borders: power and money in Central Asia, (New Haven: Yale University Press, 2017); Erica Marat, 'Global money laundering and its domestic political consequences in
} 
The post-Soviet aspect of this corruption is well-documented in both its routine (petty) and spectacular (grand) manifestations. Alena Ledeneva analyses a sistema of informal clientelist networks, integral to how Russia is governed, which have evolved from the Soviet period and adapted to global capitalism. ${ }^{115}$ Karen Dawisha demonstrates how the economy came to be controlled by Putin's network after he moved successfully to co-opt or control Russia's 'oligarchs' of the 1990s. ${ }^{116}$ But it is important to recognise that what appears to be specifically post-Soviet is globally post-Western. Cases from both Russia and Central Asia demonstrate that the offshore financial system is integral to grand corruption as it enables mobility, security and secrecy for monies earned from resource capture. As Alexander Cooley and John Heathershaw show, Central Asia is just as much part of this de-centred system as any other world region with a global network which connects London and New York to Moscow, Bishkek and Dushanbe via the British Virgin Islands, the Caymans, Cyprus, Gibraltar, Guernsey, and Hong Kong among other places. ${ }^{117}$ Thus, we find the profits of Tajik aluminium - estimated at a quarter of Tajik GDP over the period from 2005-2015 - transferred to BVI accounts and its disputes with the Russian Aluminium company adjudicated in UK and Swiss courts. ${ }^{118}$ More globally still, Kyrgyzstan's Asia-Universal Bank was set up as a node in the global financial system with tens of billions of dollars flowing in and out of the company to/from offshore accounts from Belize to New Zealand in the few years of its existence before the fall of Bakiev regime in 2010. ${ }^{119}$

\section{Conclusions: towards area studies of global politics}

The evidence presented here demonstrates that post-Western international relations are present in Russian foreign policy and Central Asian affairs to varying degrees. These are two distinct modes of the post-Western which are related but must not be conflated. First, as discussed in Section Three and as has been widely observed elsewhere, Russia substantively mimics the West as a post-imperial state, and challenges commonly accepted meanings of the key concepts and practices of the international community. ${ }^{120}$ Russia's strength in the international system means it does not have to resort so frequently to practices of metis vis-à-vis Western hegemonic projects, but can instead employ substantive mimicry to undermine their legitimacy and expose their inconsistencies. The post-Western condition thus implies a greater amount of agency and subversive capacity than the postcolonial condition, at least in the context of Russia and Central Asia.

Second, as argued in Section Four, there are formal mimicry and mētis with Kyrgyzstan and Tajikistan's relations with the former colonial power. Central Asia is a region emerging as properly post-Western in its rejection both of the Russian/Soviet past and the Western-sponsored 'transition' process of the 1990s. Russia's international relations in this region underline the acceptance of its neo-colonial projects on the surface alongside a subtle but firm resistance to full-fledged Russian hegemony, which occasionally leads to push-backs. ${ }^{121}$ Relations between Russia and it postcolonies, as articulated by our interviewees, are ones based on ambivalence. Nascent discourses of mimicry and basic practices of mētis reflect, on the one hand, disillusionment with Russia and, on the other, dependence on it, echoing the postcolonial experience more broadly. To borrow from Moore, these relations equivocate 'between the desire for autonomy and a history of dependence, between the desire for autochthony and the fact

\footnotetext{
Kyrgyzstan', Central Asian Survey, Volume 34 (1), 2015, pp. 46-56; Kemel Toktomushev, 'Regime security, base politics and rent-seeking: the local and global political economies of the American air base in Kyrgyzstan, 2001-2010', Central Asian Survey, Volume 34 (1), 2015, pp. 57-77.

115 Alena Ledeneva, Can Russia Modernise? Sistema, Power Networks and Informal Governance, (Cambridge: Cambridge University Press, 2013).

${ }^{116}$ Karen Dawisha, Putin's Kleptocracy: Who Owns Russia? (New York: Simon \& Schuster, 2014).

117 Cooley \& Heathershaw, Dictators Without Borders

118 Ibid., pp.95-101

119 Ibid., pp.153-157

${ }^{120}$ Morozov, Russia's Postcolonial Identity; Zarakol, After Empire.

${ }^{121}$ See, for example, Kyrgyzstan's American airbase (2001-14), which was continued against Russia's wishes, and Tajikistan rejection of Russian investment in favour of Chinese and even Western commerce (especially after the summit between Putin and Rahmon in 2005).
} 
of hybrid part-colonial origin, between resistance and complicity, between imitation (or mimicry) and originality'. ${ }^{122}$

These two modes of the post-Western together enable us to sketch out an analytical framework which is global without being specifically Western. Four remarks may be made by way of conclusion regarding the theoretical import of the postcolonial mode of the post-Western. The first three of these are ontological and a fourth methodological. Firstly, this analytical path enables us to shift the focus away from the Western vs non-Western dyad that is the primary focus in analyses of international politics, to relations between, entanglements of, and collaboration among these actors at a global scale. Mimicry and mētis are globally instantiated phenomena even when they have specific manifestations in great power politics (Russia's EEU project simultaneously mimicking and competing with the EU) and regional affairs (Central Asian extraction industries incorporation into the global offshore networks). Secondly, the dual focus on the postcolonial state as object and its constitutive elite as agents accurately reflects the embedded nature of agency. It decentres analysis away from an exclusive focus on the state as institution to the elite networks that flow through the state. Thirdly, mimicry and metis are concepts within post-Western structures that are global. There is not a country in the world that has not been touched by colonialism, either as coloniser or colonised. They therefore allow the possible for commensurable claims and shared conversations about global politics upon which to begin the construction of theories. As discussed above, the alternative to this approach is either to accept the inevitably imperial optic of IR or embark on a conception of IR as comparative regional studies, as the proponents of non-Western IR imply. Fourthly, the concepts demand methodologies which pay attention to practice. Mimicry, as an elite practice, is primarily accessible through the discourse at the postcolonial state level, evident in the rationale given for the development of laws, political institutions and foreign policy decisions. Mētis, as the practice of citizens, can be uncovered through ethnographic fieldwork and participant observation. A modest attempt in this direction has been attempted in this paper, but a great deal of possible mêtis was invisible to this study due to the methods used.

As our modest and illustrative study has shown, mimicry and mētis, although features of the postcolonial form of post-Western IR, are not necessarily markers of the decolonisation of international politics. There are variations in the extent of the postcolonial, as is evident in our partial examples of mimicry and mētis. Like modernities, postcolonial relations are not simply multiple but asymmetrically entangled. ${ }^{123}$ There are methodological and epistemological challenges found in this entanglement: in the need to incorporate the micro with the macro, and to do so in a manner that is able to capture the different strands of the postcolonial. The combination of ethnographic fieldwork with discourse analysis is hard to achieve without a focus on a particular region and its languages at the expense of other neighbourhoods of the post-Western world and other manifestations of the postcolonial conditions. This is an immense challenge of research design and its limits. Collaborative research for the co-production of knowledge internationally (often between major Western universities and institutions and independent researchers of the 'non-West') is both a moral and practical necessity. In its research design, ontologically and methodologically, a postcolonially informed post-Western IR must be reflexive, that is, able to reflect on the problems of ethnocentrism without discarding the claim to universal value. ${ }^{124}$

\footnotetext{
122 Moore, 'Is the Post- in Postcolonial the Post- in Post-Soviet?', p. 112.

${ }^{123}$ Shmuel N. Eisenstadt, 'Multiple Modernities', Daedalus, 129 (2000), pp. 1-29; Göran Therborn, 'Entangled

Modernities,' European Journal of Social Theory, 6: 3 (2003), pp. 293-305; Till Mostowlansky, Azan on the

Moon: Entangling Modernities along Tajikistan's Pamir Highway, Dissertation Thesis: University of Bern, 2013.

${ }^{124}$ See also Patrick Jackson, The Conduct of Inquiry in International Relations, (Abingdon: Routledge, 2011).
} 